\title{
Krzysztof Korży*
}

\section{Imponderabilia perswazyjne (Poza)kognitywne uwarunkowania skuteczności argumentacji}

\section{Uwagi wstępne}

Działania perswazyjne, o których tu mowa, to wieloskładnikowe i wieloetapowe procesy bądź łańcuchy czynności słownych i pozasłownych mające na celu takie pokierowanie biegiem myśli partnera interakcji oraz wpłynięcie na jego uczucia i zamiary, by ostatecznie zachował się on w sposób pożądany z punktu widzenia osoby argumentującej czy perswadującej. Mówiąc krótko - chodzi o zmiany postaw lub zachowań podmiotu korzystne przede wszystkim dla wywierającego ów wpływ. Za część tak rozumianej perswazji będę uważał również argumentowanie, czyli przedstawianie ciągów semantycznie ze sobą powiązanych zdań o charakterze przesłanek prowadzących w przekonaniu prezentującej je osoby do wynikającej z nich - w sensie logicznym - konkluzji lub będących uzasadnieniem tezy bronionej przez ową osobę ${ }^{1}$. Skutki takich poczynań zależą, rzecz prosta, tyleż od obranej strategii perswazyjnej czy argumentacyjnej oraz psychofizycznej podatno-

* Dr, Katedra Filozofii Umysłu i Kognitywistyki, Instytut Filozofii, Akademia Ignatianum w Krakowie, e-mail: krzysztof.korzyk@ignatianum.edu.pl.

1 Według Marka Tokarza: „Właściwości strukturalne komunikacji perswazyjnej można analizować z co najmniej dwóch punktów widzenia: formalnego (syntaktyczno-semantycznego) i funkcjonalnego (pragmatycznego). Z perspektywy formalnej poszukuje się uniwersaliów i niezmienników, czyli takich zasad organizacyjnych, którym podlegają wszystkie bez wyjątku przekazy perswazyjne; z perspektywy funkcjonalnej zaś różnicuje się je zależnie od sytuacji komunikacyjnej, z uwzględnieniem celów przyświecających nadawcy i stosowanych przez niego strategii”, w: tenże, Argumentacja i perswazja, „Filozofia Nauki” 2003, nr 1(41), s. 32. Zgodnie z tym rozróżnieniem, przyjmuję tu funkcjonalno-pragmatyczny punkt widzenia w odniesieniu do szeroko pojętych wypowiedzi perswazyjnych i argumentacyjnych. 
ści na nią konkretnych podmiotów, ileż od okoliczności ich stosowania opatrywanych zwykle pojemnym mianem „kontekstu sytuacyjnego”.

W klasycznej, wywodzącej się ze starożytności tradycji retorycznej, elementy mające wpływ na decyzje podmiotów w tej sferze - zwłaszcza związane z użyciem konkretnych strategii argumentacyjnych i środków przekonywania bądź perswazji - grupowano w poręczne kategorie éthosu, pathosu i lógosu ${ }^{2}$. Pierwsza z nich obejmowała szeroko pojętą wiarygodność mówcy wynikającą z jego charakteru, wykształcenia, wiedzy, umiejętności, zasług itd.; druga - jego zdolność czy umiejętność wpływania na emocje i uczucia słuchaczy oraz utrzymywania ich w stanie podatności na przedstawiane sugestie interpretacyjne; trzecia - wszystko to, co składało się na merytoryczną wartość wywodu bądź dowodzenia ocenianą z punktu widzenia logiki, semantyki i - horrribile dictu - pragmatyki, pojmowaną wszakże nie tyle jako ścisła zgodność z odnośnymi prawami logiki formalnej, ile raczej jako stopniowalna własność logicznego uzasadnienia konkluzji bądź też miara akceptowalności dowodzonych tez.

Z kolei, z punktu widzenia współczesnych teorii argumentacji i perswazji, można - zdaniem Marka Tokarza - wyodrębnić cztery konstytutywne elementy perswazji:

(a) akt perswazyjny ma zawsze miejsce w jakiejś sytuacji; (b) akt ten - potencjalnie - jest w stanie zmienić ową sytuację; (c) perswazja jest podejmowana w tym właśnie celu, aby zmodyfikować zastaną sytuację w zaplanowanym z góry, dogodnym dla nadawcy kierunku; (d) realna zmiana, wywołana emisją komunikatu, może nie pokrywać się ze zmianą planowanąa ${ }^{3}$.

W prowadzonych tu rozważaniach interesują mnie przede wszystkim szeroko pojęte sytuacyjne uwarunkowania skuteczności takich działań, które - zgodnie z tradycją - będę nazywał uwarunkowaniami kontekstowymi. Abstrahując od rygorystycznych wymogów logiki formalnej nakładanych na procedury uzasadniania przekonań za pomocą niezawodnych schematów wnioskowania, zajmę się więc sygnalizowanymi w tytule kognitywnymi i pozakognitywnymi uwarunko-

2 Por. np. Arystoteles, Retoryka. Retoryka dla Aleksandra. Poetyka, przeł. H. Podbielski, Warszawa 1988, gdzie czytamy: „Środki przekonywania, uzyskane za pośrednictwem mowy, dzielą się na trzy rodzaje. Jedne z nich zależą od charakteru mówcy [éthos], inne od nastawienia, w jakie wprawia się słuchacza [pathos], inne jeszcze - od samej mowy ze względu na rzeczywiste lub pozorne dowodzenie [lógos]. Przekonanie dzięki charakterowi mówcy rodzi się wówczas, gdy mowa wypowiadana jest w sposób, który czyni mówcę wiarygodnym", tamże, s. 67; zob. także: P.H. Lewiński, Neosofistyka: argumentacja retoryczna w komunikacji potocznej, Wrocław 2012; E. Modrzejewska, Lógos, éthos, pathos w praktyce medialno-politycznej. Środki przekonywania w cytowanych wypowiedziach opozycji, „Forum Artis Rhetoricae” 2012, nr 2, s. 55-78.

3 M. Tokarz, dz. cyt., s. 32. Zob. także, tenże, Argumentacja, perswazja, manipulacja, Gdańsk 2006. 
waniami skuteczności argumentacji, nazywanymi dla wygody imponderabiliami perswazyjnymi, ze względu na dobrze znane trudności z operacjonalizacją ich oddziaływania w konkretnych sytuacjach problemowych czy zadaniowych ${ }^{4}$.

\section{Logiczny i potoczny wymiar argumentacji}

Z punktu widzenia logiki wzorcowymi strukturami wyznaczającymi standardy poprawności rozumowań są schematy wnioskowania dedukcyjnego, w których wypadku wnioski wynikające logicznie - w technicznym sensie tego terminu - z przesłanek są bezwzględnie prawdziwe. Jak przypomina Tokarz:

Logicy o orientacji formalnej wymagają, aby wszelkie poprawne wnioskowania dawały się sprowadzić do takiej [...] idealnej formy. Osiągnięcie stanu logicznego ideału jest jednak okupione ciężkim grzechem, z którego logicy rzadko zdają sobie sprawę. Grzech, o którym mowa, polega na braku realizmu. Wnioskowania dedukcyjne są możliwe wyłącznie w odniesieniu do abstrakcji i miraży - udaje się je zastosować jedynie w dyscyplinach takich jak matematyka i teologia. Rozumowania prowadzone na potrzeby życia codziennego, a także na potrzeby nauk społecznych i humanistycznych, warunku poprawności dedukcyjnej po prostu spełnić nie mogą. Doskonałość [...] argumentacji [tego rodzaju] ma bowiem swoje źródło w doskonalości świata, którego ona dotyczy. Nie ma w tym świecie miejsca dla wypowiedzi niezupełnie prawdziwych i wniosków niezupełnie pewnych ${ }^{5}$.

Konsekwentnie więc, zdaniem przywołanego badacza:

Jednak w realnym życiu nie dysponujemy ani takimi stuprocentowo pewnymi danymi wyjściowymi, ani też stuprocentowo poprawnymi regułami inferencji. Z czysto logicznego punktu widzenia sytuacja wygląda więc tak. Możemy wprawdzie udowodnić najbardziej wyrafinowane twierdzenia, takie jak twierdzenie o niezupełno-

4 Obszerne omówienie tych kwestii przynosi przywoływane już, świetne studium Tokarza. Zob. także: P.H. Lewiński, Retoryka a nauka, „Forum Artis Rhetoricae” 2015, nr 4, s. 27-47; J.Z. Lichański, Badania nad retoryka w Polsce: wprowadzenie do bibliografii, „Forum Artis Rhetoricae" 2012, nr 1(28), s. 27-67; tenże, Retoryka - argumentacja. Prolegomena do logiki rozumowań o przesłankach niepewnych, [w:] Pragmatyka, retoryka, argumentacja. Obrazy języka i dyskursu w naukach humanistycznych, red. P. Stalmaszczyk, P. Cap, Kraków 2014, s. 19-41; tenże, Research in Rhetoric in Poland (2001-2013): Introduction to Bibliography, "Forum Artis Rhetoricae" 2014, nr 1(36), s. 7-68; tenże, Polska bibliografia retoryczna 2001-2014: uzupełnienia, część l, „Forum Artis Rhetoricae” 2014, nr 4(39), s. 68-78; K. Szymanek, „Onus probandi”, jego funkcje i uwarunkowania, „Folia Philosophica” 2006, nr 24, s. 242-255; tenże, O teoriach spiskowych, „Folia Philosophica” 2012, nr 30, s. 259-281; J. Ziomek, Retoryka opisowa, Wrocław 1990.

5 M. Tokarz, Argumentacja i perswazja, s. 11. 
ści arytmetyki czy niezależności hipotezy continuum, pod takim wszakże warunkiem, iż twierdzenia te dotyczą światów idealnych. Za to w odniesieniu do świata rzeczywistego nie jesteśmy w stanie udowodnić (czyli wykazać w sposób logicznie bezbłędny) absolutnie niczego, nawet prawdy tak oczywistej jak ta, że w tramwaju powinno się ustępować miejsca staruszkom. Tymczasem, takie właśnie są "tezy”, których „dowodzimy” na potrzeby dnia codziennego ${ }^{6}$.

Jeśli zatem pamiętać, że argumentacja w kwestiach świata rzeczywistego nie jest i nie może być dowodem w technicznym rozumieniu logiki formalnej, nietrudno będzie zauważyć, że i „koniecznościowa” metaforyka standardowo towarzysząca myśleniu i mówieniu o zależnościach między elementami wnioskowania, zgodnie z którą konkluzje „wynikają” z przesłanek, tak że uznanie ich prawdziwości „pociąga za sobą" uznanie wniosków, jest w sytuacjach potocznych nie tyle opisem stanu faktycznego, niezależnego od czyjejkolwiek interpretacji, ile raczej środkiem perswazyjnym mającym wzmocnić siłę czy wymowę twierdzenia formułowanego w konkretnej sytuacji dyskursywnej.

Owa metaforyka, uzasadniona w odniesieniu do formalno-logicznych zależności między konstruktami teoretycznymi wyznaczającymi normy racjonalności w naukach analitycznych, nie zdaje sprawy $\mathrm{z}$ aktywnego uczestnictwa podmiotu w procesie dochodzenia do konkluzji, które warto byłoby uznać za prawdziwe (czy co najmniej prawdopodobne). Z punktu widzenia psychologii rozumujący podmiot (choćby nawet czynił to, posługując się niezawodnymi schematami wnioskowania) wykonuje czynności poznawcze z trudnością poddające się algorytmizacji czy formalizacji, wymagające natomiast twórczej pracy wyobraźni wspieranej działaniem mechanizmów kategoryzacji, analogii, porównywania własności obiektów, generalizacji i partykularyzacji, schematyzacji i elaboracji etc. W rezultacie takich zabiegów pojawiają się w jego świadomości konstatacje, które nie tyle „wynikają” czy „narzucają się same”, ile raczej są wyprowadzane bądź wywnioskowywane w odniesieniu do wiedzy, umiejętności, inteligencji oraz sprawności podmiotu w posługiwaniu się narzędziami „intelektualnej obróbki” problemów w sytuacji zadaniowej, z którą przyszło mu się zmierzyć.

Rzeczywiste uwarunkowania konkretnych czynności i procesów poznawczych - psychologiczne, kognitywne, dyskursywne i sytuacyjne - w których wyniku dochodzi się do uznania prawdziwości konkretnych stwierdzeń, nie są zwykle przedmiotem badań logicznych, poza nurtem bezpośrednio zainteresowanym rozumowaniami potocznymi czy nieformalnymi? .

\section{Tamże, s. 12.}

7 Zob. np. F.H. van Eemeren, R. Grootendorst, Argumentation, Communication and Fallacies, Hillsdale, NJ 1992; T. Hołówka, Myślenie potoczne. Heterogeniczność zdrowego rozsądku, Warszawa 1996; taż, Błędy, spory, argumenty. Szkice z logiki stosowanej, Warszawa 1998; J.A. Blair, R.H. Johnson, The 
W związku z tym, warto zauważyć, że:

Grzech braku realizmu w teorii, wedle której argumentacja to tyle co dowód, ma jeszcze jeden aspekt. Teoria ta mianowicie analizuje struktury dowodowe jako byty całkowicie abstrakcyjne - logicy nie przejawiają najmniejszego zainteresowania ani nadawcami, ani odbiorcami tych struktur. Tymczasem teoretyczna poprawność danej argumentacji to rzecz jedna, a stopień, w jakim zdoła ona przekonać konkretnego odbiorcę to rzecz zupełnie inna. W realnym życiu „środki dowodowe” muszą być dobierane stosownie do okoliczności towarzyszących przekazowi. W przeciwnym razie argumentacja, choćby logicznie była bez zarzutu, może odbiorcy nie przekonać. Uwzględnienie tego aspektu prowadzi do pojęcia perswazji, znacznie pojemniejszego od pojęcia argumentacji, obejmującego swoim zasięgiem każdą aktywność komunikacyjną, której świadomym celem jest wywołanie zmiany albo w systemie postaw lub przekonań adresata, albo wręcz w jego zachowaniu. To z szerszą dziedziną perswazji, a nie $\mathrm{z}$ argumentacją, związana jest Arystotelesowska triada logos, ethos i pathos ${ }^{\mathbf{8}}$.

Przyglądając się z takiej perspektywy argumentacji i perswazji, nietrudno zauważyć, iż „naturalnym środowiskiem” owych „środków dowodowych” jest nie tyle kontekst, do którego zwykle odnoszą je badacze zainteresowani formalnymi czy logicznymi aspektami poprawności rozumowań i prawdziwości uzyskanych wniosków, ile raczej wspomniane wyżej „okoliczności towarzyszące przekazowi”, spośród których za najważniejszą uznaję stan umysłu partnerów interakcjị, w szczególności: aktyw-

Recent Development of Informal Logic, [w:] Informal Logic: The First Internatio-nal, red. J.A. Blair, R.H. Johnson, Inverness, CA 1980, s. 3-28; R.H. Johnson, J.A. Blair, Informal Logic: The Past Five Years 1978-1983, „American Philosophical Quarterly” 1985, no. 22, s. 181-196; R.H. Johnson, J.A. Blair, Informal Logic: Past and Present, [w:] New Essays in Informal Logic, red. R.H. Johnson, Newport News 1994, S. 32-51; R.H. Johnson, Manifest Rationality: A Pragmatic Theory of Argument, Mahwah, NJ 2000; R.C. Pinto, Argument, Inference and Dialectic: Collected Papers on Informal Logic, with an introduction by H.V. Hansen, Dordrecht-Boston 2001; D.N. Walton, Informal Logic: A Pragmatic Approach, Cambridge 2008.

8 M. Tokarz, dz. cyt., s. 13-14.

9 Przywołując tytuł i zawartość jednej z książek Talmy'ego Givóna, Context as Other Minds: The Pragmatics of Sociality, Cognition and Communication, Amsterdam-Philadelphia 2005, można uznać, że interesujący mnie tu kontekst perswazji i argumentacji obejmuje zdarzenia, czynności i procesy kognitywne zachodzące w umysłach partnerów interakcji wraz z treścią reprezentacji umysłowych wykorzystywanych przez nich w związku z ową aktywnością. Takie rozumienie terminu jest zasadniczo zgodne z sensem, jaki ma on w pragmatyce Grice'owskiej i pogrice'owskiej, m.in. w teorii relewancji Dana Sperbera i Deirdre Wilson oraz w koncepcjach Diane Blakemore i Robyn Carston. Zob. D. Blakemore, Relevance and Linguistic Meaning: The Semantics and Pragmatics of Discourse Markers, Oxford 2002; R. Carston, Thoughts and Utterances: The Pragmatics of Explicit Communication, Oxford 2002; P. Grice, Studies in the Way 
nie obecną w wymianie konwersacyjnej podmiotowo uwarunkowaną wizję rzeczywistości, do której - jako do swoistego, centralnego systemu uprawomocniania prawdziwości czy po prostu wartości przesłanek i konkluzji - odwołuje się zarówno argumentujący, jak i osoba będąca przedmiotem jego zabiegów perswazyjnych.

\section{Wizja i racjonalność dyskursywna}

Owa wizja rzadko bywa przedmiotem bezpośredniego zainteresowania badaczy zjawisk perswazyjnych, choć przecież to ona właśnie jest, jak wspomniałem, główną sferą odniesienia interpretowanych komunikatów. Jej dwie narzucające się uwadze cechy - to niewymagająca uzasadnienia oczywistość składających się na nią elementów oraz amalgamatyczność ich połączenia - obie skutkujące słabą podatnością konstruktu na zmiany. Wizję, o której mowa, współtworzą więc intuicyjnie oczywiste i aksjologicznie uwarunkowane, niepowątpiewalne przeświadczenia konstytuujące podstawy naszego oglądu świata realnego i społecznego czy po prostu rzeczywistości, wraz z towarzyszącymi im przekonaniami dotyczącymi wszystkiego, co podmiotowo istotne dla radzenia sobie z ową rzeczywistością w jej różnorodnych aspektach i przejawach. Charakterystyczne również, że wartość, nie mówiąc już o prawdziwości, wielu elementów tak scharakteryzowanego konstruktu nie tylko nie daje się w pełni uzasadnić za pomocą logicznie poprawnej argumentacji, lecz często nie jest nawet uchwytna w dyskursie spełniającym standardy logicznie pojmowanej racjonalności.

Mimo tego, to właśnie $z$ owego repozytorium pochodzą pragmatycznie umotywowane, podmiotowe rekonstrukcje obiektywnie istniejących zjawisk, zdarzeń, stanów rzeczy itd. tworzone w miarę potrzeby na użytek aktualnej sytuacji problemowej bądź zadaniowej. Proces ten przebiega zwykle w dużym stopniu poza kontrolą świadomości, bowiem partnerom zaangażowanym w dyskurs perswazyjny najczęściej trudno zaplanować wszystkie elementy wystąpienia lub choćby samą strukturę argumentacji zgodnie z zasadami logiki, prakseologii czy zwykłej, retorycznej skuteczności. W takiej sytuacji działa się raczej pod kontrolą „automatycznego pilota" - swoistego modułu poznawczego wyposażenia umysłu prowadzącego interlokutorów przez meandry dyskursu perswazyjnego dzięki wypełnianiu miejsc niedookreślenia nieujętych w planie owej aktywności „wartościami domyślnymi" pochodzącymi z zasobów centralnego systemu uprawomocnień oraz będących w jego dyspozycji sieci wiedzy, ram interpretacyjnych, modeli kognitywnych, schematów bądź innych elementów poznawczej architektury umysłu. Owymi wartościami mogą być, między innymi, treści wystandaryzowane aksjologicznie, elementy światopoglądów i ideologii, składowe racjonalności potocznej,

of Words, Cambridge, MA 1989; D. Sperber, D. Wilson, Relewancja. Komunikacja i poznanie, red. nauk. M. Jodłowiec, A. Piskorska, Kraków 2011. 
wreszcie - wysubtelnione czy wyrafinowane formy myślenia filozoficznego i logicznego, czy w ogóle - naukowego.

Interpretując omawianą aktywność podmiotu z takiej perspektywy oraz przywołując odnośne elementy metaforyki informatyczno-komputerowej, można stwierdzić, że standardowe, logiczne i retoryczne narzędzia perswazji i argumentacji funkcjonalnie przypominają elementy programów komputerowych, a posługiwanie się owymi narzędziami - zalgorytmizowane procedury operowania danymi działające poprawnie jedynie w określonym, wymodelowanym wcześniej środowisku konkretnego „systemu operacyjnego umysłu” - na przykład takim, jakie opisuje teoria relewancji (w odniesieniu do komputerów byłyby to: Unix, Linux czy DOS, by wspomnieć tylko o najpopularniejszych) - i bezużyteczne poza nim.

Na konieczność bliższego przyjrzenia się działaniu owych mechanizmów, zwłaszcza w odniesieniu do filozofii i logiki - czyli sfer racjonalnej aktywności o najbardziej wyrafinowanych standardach rozumowania - wskazywał również Alfred Gawroński, pisząc w Kształceniu filozoficznej wizji:

Istnieje dosyć rozpowszechnione przekonanie, że teoria filozoficzna jest (albo powinna być) konstrukcją podobną do gmachu o kształcie wieży, w którym wszystko trzyma się od fundamentów aż do szczytu, zespolone spoiwem racjonalnych argumentów. $U$ podstaw takiego gmachu leżą tzw. przesłanki, czyli pewne nie kwestionowane prawdy, na które nakładają się kolejne piętra argumentów o charakterze koniecznych wniosków logicznych aż do piętra najwyższego, w którym mieszczą się konkluzje. Argumenty mają służyć temu, by udowodnić, że konkluzje wynikają z przesłanek na mocy tak czy inaczej rozumianych praw wynikania logicznego. Zdarza się, że jakiś autor źle pojmuje i stosuje te prawa, ale nie zmienia to zasadniczej tezy, iż w filozofii można opracować argumenty rozstrzygające, które zmuszają nas do przyjęcia pewnych konkluzji, jeśli przyjęliśmy dane przesłanki.

Od pewnego czasu niektórzy filozofowie analityczni zwracają uwagę na fakt, że żadna teoria filozoficzna nie spełnia tych kryteriów, że nie jest i nie może być tak skonstruowana. Składają się na to różne przyczyny, z których najważniejsze da się sprowadzić do jednej: nie ma w filozofii argumentów rozstrzygających, tzw. knock down arguments, które mogą zmusić kogoś do przyjęcia konkluzji, jakich nie chce on przyjąć. Argumentacja oparta o ścisłe wnioskowanie dedukcyjne [...] dotyczyć może w tekstach filozoficznych tylko spraw marginesowych o zabarwieniu truistycznym. Wyrażenia języków naturalnych spełniają w zdaniach inną rolę niż symbole w logice formalnej [...], rolę, która [...] sprawia, że w argumentacji filozoficznej możemy stwarzać tylko pozory konieczności. Traktowanie jakiejkolwiek teorii filozoficznej jako linearnego ciągu ścisłych wniosków dedukcyjnych od przesłanek do konkluzji jest więc nieporozumieniem ${ }^{10}$.

10 A. Gawroński, Kształcenie filozoficznej wizji, [w:] tenże, Wizja i argumentacja w filozofii. Od lektury Homera do teorii metatekstu, Kraków 2011, s. 19. 
W związku z tym, cytowany badacz wskazuje w dziejach myśli filozoficznej co najmniej dwa źródła poznania, którym towarzyszą wyraźnie odmienne strategie uzasadniania przekonań. Jednym z nich jest racjonalny namysł i wynikająca zeń argumentacja. Drugim - bezpośredni wgląd w istotę tego, co badane, będący rezultatem poznania niedyskursywnego osiąganego dzięki wykształceniu przez podmiot umiejętności dostrzegania tego, czego człowiek „niewyrobiony” zobaczyć nie potrafi. Pochodną owego wglądu jest swoista wizja rzeczywistości tworząca rdzeń teorii filozoficznej uzasadnianej następnie raczej przez odwoływanie się do obrazów i modeli rzeczywistości narzucających się wyobraźni z siłą oczywistości niż przez zastosowanie rygorystycznych procedur logicznych ${ }^{11}$.

Oczywiście, jak wyjaśnia Gawroński:

Między jednym źródłem poznania a drugim, czyli między racjonalną argumentacją a wizją, wytwarza się coś w rodzaju sprzężenia zwrotnego: filozof zaczyna od pewnej wizji, ale w trakcie jej wyjaśniania i racjonalnego uzasadniania, w trakcie ustosunkowywania się do argumentów przeciwnych i faktów pozornie jej zaprzeczających, sama wizja ulega lub może ulec pewnym zmianom.

Pozostaje jednak faktem, że w każdym tekście filozoficznym - a w każdym razie $\mathrm{w}$ tekście filozoficznym racjonalnie skonstruowanym - zawsze możemy odróżnić to, co jest produktem wizji, od argumentacji w ścisłym sensie. Zdania tekstu przedstawiające daną wizję odwołują się do kryterium oczywistości lub do pewnego obrazu rzeczywistości (w każdym tekście filozoficznym mamy takie zdania), natomiast zdania argumentacyjne odwołują się do tak czy inaczej rozumianych praw wynikania logicznego. Chociaż w każdej teorii filozoficznej mamy do czynienia z jednym i drugim rodzajem zdań, to znaczenie, jakie w danej teorii przypisuje się jednemu lub drugiemu, różni się znacznie w zależności od szkoły filozoficznej i tradycji, do których dana teoria lub szkoła nawiązują ${ }^{12}$.

Charakterystyczne, że ważne pytania filozoficzne, zwłaszcza takie, które dotyczą naszej własnej wartości, znaczenia oraz godności, wiążą się z tym, co nieuwarunkowane - również przez racjonalne struktury naszego umysłu. Uprzystępnianiu tego, czego się doświadczyło w kierowanym intuicją zażyłym obcowaniu z przedmiotem poznania, służy właśnie pojęciowa artykulacja wizji przekładająca bezpośredniość uzyskanego wglądu na ciąg konstatacji, których wartość można oceniać z punktu widzenia logiki i standardów dyskursywnej racjonalności, pojmowanych choćby tak, jak czynią to dwaj przedstawiciele amsterdamskiej szkoły badań nad argumentacją i komunikacją retoryczną, Frans Hendrik van Eemeren

11 Parafrazuję tu sformułowania autora. Por. A. Gawroński, dz. cyt., s. 20.

12 Tamże, s. 20-21. 
i Rob Grootendorst. Stworzony przez nich model dyskusji krytycznej ${ }^{13}$ - sokratejski z ducha i uwzględniający Stephena Toulmina koncepcję krytycznego rozumowania - integruje pragmatyczne, dialektyczne i retoryczne funkcje argumentacji. Ma przy tym charakter tyleż heurystyczny - składa się bowiem z listy wytycznych, którymi powinni się kierować partnerzy dyskusji - ileż krytyczny, bo poszczególne ruchy argumentacyjne ocenia się tam ze względu na ich wkład w rozwiązanie problemu bądź usunięcie rozbieżności. Jak pisze jeden z komentatorów, przestrzeganie zasad i postulatów zaproponowanych przez obu badaczy „zapewniać ma maksymalną skuteczność dyskusji jako metody racjonalnego rozstrzygania sporów i eliminowania różnic opinii"14. Do mocnych stron modelu należy wyznaczenie „przestrzeni kontrowersji”, dzięki wprowadzeniu kategorii zawartości treściowej wspólnej dla stanowisk reprezentowanych przez poszczególnych uczestników sporu, określeniu jego rodzajów i etapów oraz wskazaniu całościowych relacji między argumentami i kontrargumentami. Do słabszych - silnie idealizacyjny charakter i abstrahowanie od wielu zjawisk natury poznawczej będących naturalną konsekwencją dyskursywno-komunikacyjnego współdziałania partnerów interakcji. Proponowana przez holenderskich badaczy struktura teoretyczna wysuwa na pierwszy plan kognitywne aspekty działań partnerów uchwytne za pomocą narzędzi analizy logicznej, na dalszy plan przesuwając pozakognitywne i pozaracjonalne - w sensie racjonalności typu logicznego - uwarunkowania posługiwania się odnośnymi strategiami argumentacyjnymi. Tymczasem to właśnie w sferze imponderabiliów argumentacyjnych można najczęściej znaleźć elementy motywujące podmioty do posłużenia się konkretnymi środkami kognitywnymi w celu uzasadnienia własnego stanowiska w kwestiach nieobojętnych aksjologicznie. Dość przypomnieć ustalenia badacza, którego zdaniem:

Zainteresowanie tymi problemami nie jest tylko teoretyczną zabawą, ale jest skierowane na pewne cele, a mianowicie na uzasadnienie naszych najgłębszych aspiracji lub na rezygnację z nich. Czy znaczy to, że owe cele, które chcemy osiągnąć, z góry determinują nasze konkluzje? Czy nie potrafilibyśmy pójść w naszym rozumowaniu za nakazem filozoficznego dowodu, gdziekolwiek by on prowadził? Odpowiedź na to pytanie nie jest prosta, gdyż w rzeczywistości nigdy nie mamy do czynienia $\mathrm{z}$ dowodem, ale $\mathrm{z}$ argumentacją o różnej mocy, która z konieczności odwołuje się

13 Zob. F.H. van Eemeren, R. Grootendorst, dz. cyt.; P.H. Lewiński, Od Arystotelesa do van Eemerena i Tindale'a. W poszukiwaniu źródeł wspótczesnej retoryki i dialektyki, [w:] Pragmatyka, retoryka, argumentacja. Obrazy języka i dyskursu w naukach humanistycznych, red. P. Stalmaszczyk, P. Cap, Kraków 2014, 43-61; K. Szymanek, Sztuka argumentacji. Słownik terminologiczny, Warszawa 2001, s. 119-120.

14 K. Szymanek, Sztuka argumentacji..., s. 119; tam też dokładniejsze omówienie stadiów dyskusji krytycznej oraz reguł jej prowadzenia. 
do obydwu źródeł poznania, a więc także do wizji, do oczywistości. Różne strategie umożliwiają nam uniknięcie konkluzji, których nie chcemy przyjąć, np. takich, które by oznaczały naszą bezwartościowość. [Ostatecznie więc] [...] filozof kładzie kres filozoficznej argumentacji wtedy, kiedy doprowadziła go ona tam, gdzie chciał się zatrzymać.

[...] moim celem jako filozofa jest dojście do takiego miejsca, w którym warto się znaleźć. O punkcie dojścia rozstrzyga więc moje poczucie wartości, nie ma bowiem żadnej absolutnej konieczności zatrzymania się w pewnym miejscu, która wynikałaby z samej argumentacji ${ }^{15}$.

\section{Uwagi końcowe}

Jak widać, w podmiotowe, pozaracjonalne zaangażowania - w sensie braku związku koniecznościowego z logiką pojętą jako rdzeń racjonalności - są uwikłane nie tylko „potoczne” wnioskowania przeprowadzane na potrzeby dnia codziennego, lecz również wyrafinowane rozumowania będące częścią rozbudowanych struktur argumentacyjnych zgodnych z metodologicznymi standardami odnośnych nauk. W takiej mierze, w jakiej dotyczą one świata rzeczywistego, nie zaś światów możliwych czy idealnych i przeprowadza się je na użytek konkretnych osób, są one nie tylko mniej czy bardziej wiernymi (re)prezentacjami zjawisk, zdarzeń i stanów rzeczy ujętymi z perspektywy interpretującego je podmiotu, lecz również narzędziami zmiany przekonań i postaw osób, do których są adresowane, włącznie z przypadkami ,argumentacyjnego monologu wewnętrznego".

Jeśliby zatem wziąć pod uwagę ich inherentnie perswazyjny charakter, wypadłoby się zgodzić z konstatacją Gawrońskiego, iż ostatecznie „celem argumentacji nie jest udowodnienie czegoś, ale wyjaśnienie trudności i otwarcie przed nami nieznanych obszarów i aspektów rzeczywistości”"16. I konsekwentnie, przyjąwszy taki punkt widzenia, można by wykazać, że siła logicznej argumentacji bierze się nie tyle z niej samej, ile raczej ze swoistego, dialektycznego napięcia między jej „potencjałem dowodowym” a gotowością, z jaką odpowiednio ukwalifikowane i zaangażowane podmioty, byłyby skłonne zaktualizować ów potencjał, dzięki odpowiedniej „rekalibracji” instrumentów uwspółmierniania wizji rzeczywistości poszczególnych uczestników wymiany argumentacyjnej.

Biorąc rzecz realistycznie, trudno nie zauważyć, że „wybór, jakiego dokona filozof, będzie zależał od tego, co jest dla niego ważniejsze, jego zaangażowanie w przesłanki czy też zaangażowanie w konkluzje. Jest mało prawdopodobne, aby taki wybór odbył się niezależnie od tego, jak bardzo danemu filozofowi zależy, aby

15 Tamże, s. 25-26.

16 A. Gawroński, dz. cyt., s. 26. 
pewne tezy były prawdziwe"17. Ostatecznie bowiem, argumentów nie wymieniają między sobą ani abstrakcyjne „maszyny logiczne”, ani niematerialne umysły, lecz konkretne, żyjące w realnym świecie podmioty, dla których ten rodzaj aktywności intelektualnej jest zaledwie środkiem do osiągania o wiele ważniejszych celów natury egzystencjalnej, czego skutkiem kognitywne i pozakognitywne uwarunkowania efektywności argumentacji splatają się ze sobą w swoisty, problemowy węzeł, który łatwiej rozciąć, mniej czy bardziej arbitralnie rozstrzygając kwestię współzależności obu tych aspektów, niż rozwikłać, pieczołowicie oddzielając od siebie poszczególne, splatające się ze sobą wątki.

\section{Bibliografia}

Arystoteles, Retoryka. Retoryka dla Aleksandra. Poetyka, przekł. H. Podbielski, Warszawa 1988.

Blair J.A., Johnson R.H., The Recent Development of Informal Logic, [w:] Informal Logic: The First International Symposium, red. J.A. Blair, R.H. Johnson, Inverness, CA 1980, s. 3-28.

Blakemore D., Relevance and Linguistic Meaning: The Semantics and Pragmatics of Discourse Markers, Oxford 2002.

Carston R., Thoughts and Utterances: The Pragmatics of Explicit Communication, Oxford 2002.

Dębowska K., Model pragma-dialektyczny a rozumowanie abdukcyjne, „Studia Semiotyczne" 2010, nr 27, s. 217-236.

Eemeren F.H. van, Grootendorst R., A Systematic Theory of Argumentation: The Pragma-Dialectical Approach, Cambridge 2004.

Eemeren F.H. van, Grootendorst R., Argumentation, Communication, and Fallacies: A Pragma-Dialectical Perspective, Hillsdale, NJ 1992.

Gawroński A., Wizja i argumentacja w filozofii. Od lektury Homera do teorii metatekstu, Kraków 2011.

Givón T., Context as Other Minds: The Pragmatics of Sociality, Cognition and Communication, Amsterdam-Philadelphia 2005.

Grice P., Studies in the Way of Words, Cambridge, MA 1989.

Hołówka T., Błędy, spory, argumenty. Szkice z logiki stosowanej, Warszawa 1998.

Hołówka T., Myślenie potoczne. Heterogeniczność zdrowego rozsadku, Warszawa 1996. Johnson R.H., Blair J.A., Informal Logic: Past and Present, [w:] New Essays in Informal Logic, red. R. Johnson, Newport News 1994, s. 32-51.

Johnson R.H., Blair J.A., Informal Logic: The Past Five Years 1978-1983, „American Philosophical Quarterly"1985, no. 22, s. 181-196.

17 Tamże. 
Johnson R.H., Blair J.A., The Current State of Informal Logic, „Informal Logic” 1987, no. 9, s. 147-151.

Johnson R.H., Manifest Rationality: A Pragmatic Theory of Argument, Mahwah, NJ 2000.

Lewiński P.H., Dialektyka - retoryka - komunikacja, [w:] Komunikatywizm w Polsce - wybrane zagadnienia z teorii i praktyki [seria: Poznawać. Tworzyć. Komunikować], red. G. Habrajska, Łódź 2011, s. 36-45.

Lewiński P.H., Neosofistyka: argumentacja retoryczna $w$ komunikacji potocznej, Wrocław 2012.

Lewiński P.H., Od Arystotelesa do van Eemerena i Tindale’a. W poszukiwaniu źródeł współczesnej retoryki i dialektyki, [w:] Pragmatyka, retoryka, argumentacja. Obrazy języka i dyskursu w naukach humanistycznych, red. P. Stalmaszczyk, P. Cap, Kraków 2014, s. 43-61.

Lewiński P.H., Retoryka a nauka, „Forum Artis Rhetoricae” 2015, nr 4, s. 27-47.

Lichański J.Z., Badania nad retoryka $w$ Polsce: wprowadzenie do bibliografii, „Forum Artis Rhetoricae" 2012, nr 1(28), s. 27-67.

Lichański J.Z., Polska bibliografia retoryczna 2001-2014: uzupetnienia, część I, „Forum Artis Rhetoricae" 2014, nr 4(39), s. 68-78.

Lichański J.Z., Research in Rhetoric in Poland (2001-2013): Introduction to Bibliography, „Forum Artis Rhetoricae” 2014, nr 1(36), s. 7-68.

Lichański J.Z., Retoryka - argumentacja. Prolegomena do logiki rozumowań o przesłankach niepewnych, [w:] Pragmatyka, retoryka, argumentacja. Obrazyjęzyka i dyskursu w naukach humanistycznych, red. P. Stalmaszczyk, P. Cap, Kraków 2014, s. 19-41.

Modrzejewska E., Lógos, éthos, pathos w praktyce medialno-politycznej. Środki przekonywania w cytowanych wypowiedziach opozycji, „Forum Artis Rhetoricae” 2012, nr 2, s. 55-78.

Pinto R.C., Argument, Inference and Dialectic: Collected Papers on Informal Logic, with an introduction by H.V. Hansen, Dordrecht-Boston 2001.

Pragmatyka, retoryka, argumentacja. Obrazy języka i dyskursu w naukach humanistycznych, red. P. Stalmaszczyk, P. Cap, Kraków 2014.

Sperber D., Wilson D., Relewancja. Komunikacja i poznanie, red. nauk. M. Jodłowiec, A. Piskorska, Kraków 2011.

Szymanek K., „Onus probandi”, jego funkcje i uwarunkowania, „Folia Philosophica” 2006, nr 24, s. 242-255.

Szymanek K., O teoriach spiskowych, „Folia Philosophica” 2012, nr 30, s. 259-281.

Szymanek K., Sztuka argumentacji. Słownik terminologiczny, Warszawa 2001.

Tokarz M., Argumentacja i perswazja, „Filozofia Nauki” 2003, nr 1(41), s. 7-41.

Tokarz M., Argumentacja, perswazja, manipulacja, Gdańsk 2006.

Walton D.N., Informal Logic: A Pragmatic Approach, Cambridge 2008.

Ziomek J., Retoryka opisowa, Wrocław 1990. 
Krzysztof Korżyk

\title{
Imponderabilia perswazyjne. (Poza)kognitywne uwarunkowania skuteczności argumentacji
}

\author{
Streszczenie
}

W przedstawianym tekście omawiam kognitywne i pozakognitywne uwarunkowania skuteczności perswazji i argumentacji, które nazywam imponderabiliami perswazyjnymi, ze względu na dobrze znane trudności z operacjonalizacją ich oddziaływania w konkretnych sytuacjach problemowych. W związku z tym zajmuję się również konstytutywnymi elementami perswazji i omawiam ich własności z funkcjonalno-pragmatycznego punktu widzenia. W szczególności, zwracam uwagę na: 1) nieprzystawalność formalno-logicznych modeli argumentacji do realiów komunikacji perswazyjnej; 2) konieczność uwzględnienia w badaniach nad argumentacją i perswazją podmiotowej, zaksjologizowanej wizji rzeczywistości jako ważnego układu odniesienia dla funkcjonowania „środków dowodowych”; 3) niejednorodność strategii uzasadniania przekonań odwołujących się do różnych źródeł poznania; 4) wagę pytań filozoficznych związanych z tym, co nieuwarunkowane w ludzkim myśleniu i egzystencji. Całości dopełniają konstatacje dotyczące nie-dowodowej i nie-koniecznościowej natury argumentacji oraz roli krytycznej dyskusji w harmonizowaniu niewspółmiernych, podmiotowych wizji rzeczywistości partnerów interakcji.

Słowa kluczowe: aksjologia, argumentacja, dyskusja, komunikacja, kontekst, logika, perswazja, postawa, przekonanie, reprezentacja, rzeczywistość, schemat, umysł, wartość, wizja, zachowanie

\section{Persuasive Imponderabilia: (Non)Cognitive Determinants of Argument Effectivity}

Summary

In this text I discuss the cognitive and non-cognitive factors that determine the effectiveness of persuasion and argumentation which I dub "persuasive imponderabilia" due to the obvious difficulties with the operationalization of their 
impact in concrete, problem-solving situations. Concurrently, I also deal with the constitutive elements of persuasion examining their inherent qualities from a functional-pragmatic viewpoint. Specific attention is paid to: 1) The incompatibility of formal-logical models of argumentation with the reality of persuasive communication; 2) The need to include in the study of argumentation and persuasion, a subjective, axiologized vision of reality, as an important reference point in the functioning of "evidence"; 3) The heterogeneity of strategies for justifying convictions and beliefs which refer to various sources of cognition; and 4) The importance of philosophical queries concerning what is undetermined in human thinking and existence. These considerations are complemented by pointing to the logical improvability and unnecessariness of the very nature of the argumentation as well as to the role of a critical discussion in minimizing belief divergence in discursive interactions.

Keywords: attitude, axiology, argument, behavior, belief, communication, context, discussion, logic, mind, persuasion, representation, reality, schema, value, vision

Krzysztof Korżyk - dr, filozof, językoznawca, kognitywista. Stypendysta The Social Sciences and Humanities Research Council of Canada, The Central European University w Budapeszcie, The Central and East European Center for Cognitive Science w Sofii, Istituto Mitteleuropeo di Cultura w Bolzano oraz The Vilem Mathesius Center for Research and Education in Semiotics and Linguistics w Pradze. Jego zainteresowania naukowe obracają się wokół filozoficznych, antropologicznych i socjologicznych aspektów funkcjonowania systemów symbolicznych w poznaniu, komunikacji i kulturze. Publikował w „Autoportrecie”, „Literaturze na Świecie”, „Tekstach Drugich”, „Zeszytach Etnologii Wrocławskiej” oraz w polskich i zagranicznych specjalistycznych wydawnictwach filozoficznych, językoznawczych i kulturoznawczych. Pracuje w Katedrze Filozofii Umysłu i Kognitywistyki Akademii Ignatianum w Krakowie. 